\title{
EFFECTS OF RICE HUSK ASH AND TERMITE HILL TYPES ON THE PHYSICAL AND MECHANICAL PROPERTIES OF BURNT TERMITE CLAY BRICKS FOR RURAL HOUSING
}

\author{
T. U. NWAKONOBI, C. P. ANYANWU AND L. R. TYAV \\ (Received 3 April 2013; Revision Accepted 28 October 2013)
}

\begin{abstract}
Clay bricks remain the most widely used materials in the building and construction industries, due to their good qualities, low cost and versatility compared to other materials for building purposes. More so, the large quantities of agricultural waste produced, such as rice husk resulting from high consumption of rice worldwide constitutes disposal problem and unhealthy environment. This waste can be recycled through inclusion as stabilizer in brick making, thereby eliminating the hazard posed to the environment. This paper examined the effects of rice husk ash (RHA) on the two termite clay soils in brick making. The two termite clay soils obtained from red and gray anthills were stabilized with rice husk ash at levels of $0-10 \%$ contents. The termite clay -rice husk bricks were fired at different temperature levels of $800^{\circ} \mathrm{C}-900^{\circ} \mathrm{C}$. The pasticity index varied upward with the addition of RHA contents. There was decreasing trend in the dry density values with increasing rice husk ash contents for both termite clay types. The inclusion of RHA in the two termite clay soils do not cause any change in optimum moisture content of the mixtures. Rice husk ash cause increase in the compressive strength of both termite clay bricks attaining maximum value at $4 \%$ and $6 \%$ for gray and red type, respectively. Further increase in the RHA content did not cause corresponding increase in the strength values of both termite clay bricks. Bricks produced from both termite clay soils attained the highest compressive strength at $900^{\circ} \mathrm{C}$ at all the RHA contents. The termite clay bricks burnt at the two temperature levels displayed increasing trend pattern in water absorption with increase in the RHA contents. There was decrease in the water absorption of both brick types burnt at higher temperature of $900^{\circ} \mathrm{C}$. The analysis of variance (ANOVA) study indicate no significance differences in the compressive strength of termite clay brick samples due to rice husk ash content, firing temperature levels and termite hill type.
\end{abstract}

KEYWORDS: Clay bricks, termite hill, rice husk ash, stabilization, strength, building construction.

\section{INTRODUCTION}

Brick is traditional building material which due to its high quality in compressive strength, moisture absorption resistant, fire resistant, fungi-mould resistant and insulation earn it wide acceptance in the construction and building industries. In developing countries, about $80 \%$ of the rural population still lives in low quality and substandard houses as they cannot afford the high cost of new building materials that can provide better dwellings and other infrastructures. Clay bricks have been identified as low cost and effective materials for dwellings and other infrastructures.

According to Horng (2010) bricks are usually used in the making of structural components such as partition walls, building walls and retaining walls. Generally, structures built of unfired clay bricks are vulnerable to weather and moisture conditions, swelling and shrinkage potentials, not durable and are less reliable (Horng, 2010). Research efforts are directed towards improving the quality of clay bricks through stabilization with cement, lime and various agricultural wastes materials; inclusion of natural fibres and burning (fired) (Murray et al, 1981; Rahman, 1987; Demir et al, 2005; Makunza, 2006; Chan, Yetgin et al, 2008; Binici, 2009; Okeshola, 2012). Not much has been reported on the utilization and improvement of the termite clay bricks.

Termite clay is obtained from antihill (or mound) which is a pile of earth made by termite from the soil in the immediate vicinity. It is a large tower of soil stuck together with termite secretion. The termite hill (antihill) can be found anywhere in the world though highly populated in Africa and Australia. William et al, (1995) in their study reported that the termite hill samples indicate chemical composition similar to that of clay minerals. It is better material than the ordinary clay in terms of utilization for moulding lateritic bricks due to its plasticity (Odumodu, 1999, Mijinyewa et al, 2007). However there are few reports on the utilization of termite clay as material for brick production. The termite hill appear in different colours which according to Brady and Ray (2006) depend on the type of soil in its vicinity. The property of termite clay may therefore depend on the

T. U. Nwakonobi, Department of Agricultural and Environmental Engineering, University of Agriculture, Makurdi, P.M.B. 2373, Benue State, Nigeria

C. P. Anyanwu, Department of Agricultural and Environmental Engineering, University of Agriculture, Makurdi, P.M.B. 2373, Benue State, Nigeria

L. R. Tyav, Department of Agricultural and Environmental Engineering, University of Agriculture, Makurdi, P.M.B. 2373, Benue State, Nigeria 
type of soil within the immediate environment.

The increase in agricultural processes generates large quantities of waste which are disposed of in landfill and open burning. Rice Husk is an agricultural waste obtained from milling of rice. About $10^{8}$ tonnes of rice husk is generated annually in the world. In Nigeria, about 2.0 million tonnes of rice is produced annually, while in Niger state, about 96,600 tonnes of rice grains is produced in 2000 (Oyetola and Abdullahi, 2006). According to some investigators the accumulation of improperly managed wastes has raised significant environmental and sustainable concerns (Demir, 2006; Turgut et al, 2008). An on-going effort to counter this vicious cycle is to recycle and incorporate these disposable wastes in the construction industry, especially in the manufacturing of building materials. A particularly potential area for the reuse of these wastes is brick-making (Chan, 2011).

This study evaluates the influence of rice husk ash (RHA) and types of termite hill on the physical and mechanical properties of burnt or fired termite clay bricks for general building purposes.

\section{EXPERIMENTAL PROGRAM}

\section{$2.1 \quad$ Materials}

Termite clay was obtained from two different anthills; one was red and the other gray in colour (see Figs. $1 \& 2$ ), all located within the undeveloped sites of the University of Agriculture, Makurdi, Nigeria. The antihill colouration indicates the type of soil within the vicinity. Then rice husk ash (RHA) was used to stabilise the termite clay in order to improve the quality of the burnt bricks produced from it. Clean water was used to add to the termite clay-rice husk ash mixture at optimum moisture content (OMC).
The termite clay was collected in bulk from its deposit site using digger to break up the anthills. This was moved to the experimental location where it was further broken into finer sizes with the use of rammer and then air-dried. The dry sample was ground into powder form. The fine termite clay powder was to ensure enough plasticity for a uniform mix when added with the other mixture components (Chan, 2011).

\section{$2.2 \quad$ Experimental methods}

Standard soil classification tests were carried out based on the prescription of BS 1377; Part 2: 1990. To conduct the Consistency limit test, the termite clay samples were grind into fine powder to ensure uniform mix and enough plasticity when added with RHA. The material sizes finer than $63 \mu \mathrm{m}$ sieves opening were used to perform the consistency limit tests. The blending mix of $0 \%, 2 \%, 4 \%, 6 \%, 8 \%$, and $10 \%$ RHA contents (dry weight basis of Termite clay) were used for the test. Distilled water was used to obtain a uniform paste. A Cassgrande apparatus with a grooving tool was used for the limit test. The crank of the Cassagrande dish was rotated at the rate of 2 revolutions per second and the number of blows at which the groove made on the paste closed were recorded. The paste removed from the zone of the groove was subjected to the moisture content determinations using standard method.

Other limit tests such as plastic and shrinkage limits tests were performed in accordance with the procedure by BS 1377: 1990. Particle size distributions as well as specific gravity of the soil samples were also established. The results of the soil classification tests were used to classify the termite clay samples using the American Association of State High Way and Transport Officials (AASHTO) and the Unified Soil Classification System (USCS). The results of the physical properties are presented in Table

1.

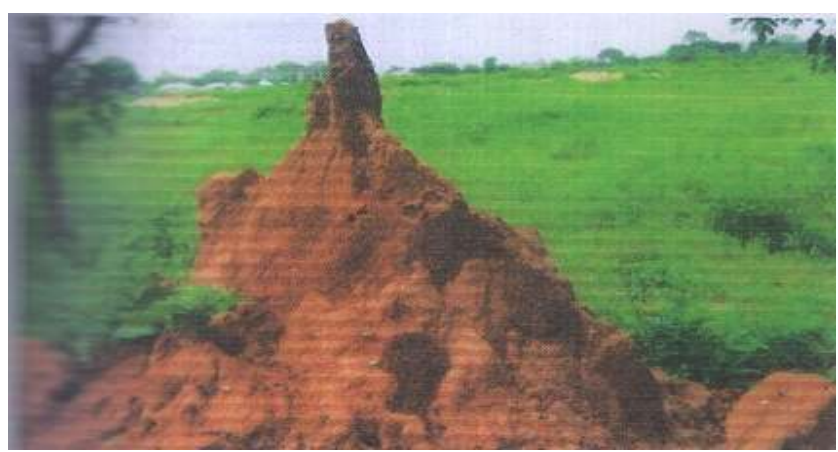

Figure 1: Red termite hill

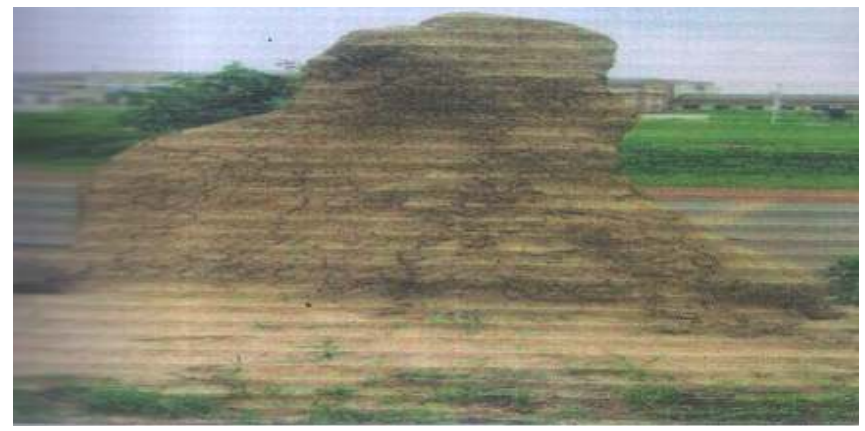

Figure 2: Gray termite hill 
Table 1: Particle Size Distribution

\begin{tabular}{|l|l|l|l|l|}
\hline \multirow{2}{*}{ Termite Clay Type } & \multicolumn{2}{|l|}{ Percentage proportion, \% } & \multirow{2}{*}{ Textural class } \\
\cline { 2 - 4 } & Clay & Silt & Sand & \\
\hline Red & 48.9 & 17.8 & 33.3 & Lean clay \\
\hline Gray & 46.5 & 23.3 & 30.2 & Lean clay \\
\hline
\end{tabular}

\subsubsection{Compaction Test}

The compaction tests on the termite clay samples were performed by passing the soil samples through $200 \mathrm{~mm}$ BS Sieve as specified in BS 1377: Part 4: 1990, for compaction test. The standard proctor (SP) or light compaction was adopted to determine the moisture - density relationship for the termite clay rice husk ash mixture with the blending ratios of $0 \%, 2 \%$, $4 \%, 6 \%, 8 \%$ and $10 \%$ RHA contents. The termite clay was compacted using energy derived from a $2.5 \mathrm{~kg}$ mass or rammer falling through a height of $300 \mathrm{~mm}$ in a $1000 \mathrm{~cm}^{3}$ mould. The clay was compacted in three layers with 27 blows on each layer. The results of this determination are presented in Table 2.

\subsection{Tests on Termite Clay Bricks Brick Making}

The termite clay lumps obtained from site for brick making was first air-dried, and ground into powder to achieve uniform mix when added with the additives, the rice husk ash. The blending mixtures of $0 \%, 2 \%, 4 \%$, $6 \%, 8 \%$ and $10 \%$ rice husk contents (of dry weight samples) were prepared. The optimum moisture content of each percentage mixture was used in the brick moulding using $40 \mathrm{~mm} * 40 \mathrm{~mm} * 40 \mathrm{~mm}$ cast iron mould. The inside of the walls of the mould were first oiled and the mixture cast and compacted. The lubrication of the mould was to ease extrusion of the bricks during demoulding. The demoulded bricks were left to gradually dry under ambient conditions for five days.

The bricks were thereafter burnt in an electric kiln. Three replicate brick specimen samples were prepared for each batch or percentage mixture. The specimens were burnt at two temperature levels of $800^{\circ} \mathrm{C}$ and $900^{\circ} \mathrm{C}$ after which they were subjected to compressive strength and water absorption tests which are the two properties that are majorly used to distinct the quality of bricks (Horng, 2010).

\subsubsection{Compressive Strength Test}

The burnt termite clay brick specimen samples were preconditioned by immersion in cold water at room temperature $\left(24^{0} \mathrm{C} \pm 2{ }^{0} \mathrm{C}\right)$ for 24 hours. After that, the specimens were removed and were wiped of the moisture and weighed for any increase in weight due to water absorption. The procedure was in accordance with the Standard Organization of Nigeria (SON, 1997). The bricks were then stored in moistened condition for 24 hours prior to testing. Each of the brick specimens was centrally positioned between the platens of the compressive strength testing machine to ensure uniform load transmission and to prevent wobbling during the test. The load was gradually applied at constant loading rate until failure.

\subsubsection{Water Absorption Test}

The test was performed by a 24 hours immersion of burnt brick specimen samples in cold water as specified by the Standard Organization of Nigeria (SON, 1997).

\section{RESULTS AND DISCUSSION}

\subsection{Particle Size Distribution}

Hydrometer test was conducted for better grading of fine grain termite clay soil. The results of the particle size distribution are presented in Table 1. The soil textural class was found to be lean clay for red and gray termite clay soils.

\subsection{Consistency Limit}

The results of the consistency limits (Atterberg Limits) tests are shown in Table 2. The test was in accordance with the procedure outlined in BS1377: 1990. The results indicate higher liquid limit values for the stabilised red and gray termite soil than the nonstabilised termite clay soil. The $6 \%$ blending mix of RHA and gray termite clay showed the highest value of $56 \%$ compared to $23.3 \%$ of the non-stabilised sample while the $8 \%$ blending mix of RHA and red termite clay indicates the highest value of $54 \%$ compared with $27 \%$ of non- stabilised. The results did not indicate any trend pattern which may be due to the soil particle dispersion.

The plastic limit of gray termite clay ranges between $8 \%-35 \%$ while red type ranges between $10 \%$ - $33 \%$. The $6 \%$ blending mix of RHA and gray termite clay shows the highest value of $35 \%$ while the $8 \%$ blending mix shows the lowest value of $8 \%$. For the red termite clay, $4 \%$ RHA content shows the highest value of $33 \%$ while the $0 \%$ RHA content shows the least plastic limit of $10 \%$. The shrinkage limit results show higher values for red type of termite clay than the gray type with slight decreasing trend with increasing RHA contents.

The plasticity index ranges from $4 \%-26 \%$ for gray termite clay and $9 \%-34 \%$ for red termite clay. The $8 \%$ blending mix of RHA shows the highest value of $26 \%$ and $34 \%$ for gray and red termite clay type, respectively.

The specific gravity of both termite clay types decreases as the RHA contents increases. The specific gravity ranges between 2.55 to 2.83 for red termite clay and ranges between $2.15-2.77$ for gray type. Both termite soils were classified based on the Unified soil Classification System (USCS) and American Association of Highway and Transportation Officials (AAHTO) as well graded sand with silt and A-7-2, respectively. Both are low to medium plastic clays. 
Table 2: Consistency Limits Test Results at Various Blending Mix of RHA and Termite clay

\begin{tabular}{|c|c|c|c|c|c|c|c|c|c|c|c|c|}
\hline \multirow{3}{*}{$\begin{array}{l}\text { Consistency } \\
\text { limit, \% }\end{array}$} & \multicolumn{12}{|c|}{ RHA Percentage Mixes } \\
\hline & \multicolumn{6}{|c|}{ Gray termite clay } & \multicolumn{6}{|c|}{ Red termite clay } \\
\hline & 0 & 2 & 4 & 6 & 8 & 10 & 0 & 2 & 4 & 6 & 8 & 10 \\
\hline Liquid limit & 23.3 & 41 & 26 & 56 & 35.5 & 36 & 27 & 30 & 42 & 34 & 54 & 34 \\
\hline Plastic limit & 14 & 26 & 16 & 35 & 8 & 32 & 10 & 19 & 33 & 20 & 20 & 15 \\
\hline Plasticity index & 10 & 15 & 11 & 21 & 26 & 4 & 17 & 10 & 9 & 14 & 34 & 19 \\
\hline Shrinkage limit & 7.10 & 5.0 & 6.4 & 6.4 & 6.4 & 6.4 & 7.9 & 7.1 & 6.8 & 7.6 & 7.3 & 7.2 \\
\hline Specific gravity & 2.77 & 2.75 & 2.48 & 2.45 & 2.44 & 2.15 & 2.83 & 2.77 & 2.65 & 2.62 & 2.58 & 2.55 \\
\hline
\end{tabular}

\subsection{Compaction Characteristics}

The compaction test was conducted to measure the moisture density relationship which was in accordance with BS1377: part 4: 1990 and the results are presented in Table 3 . The maximum dry density (MDD) indicates a decreasing trend pattern with the increase in RHA content for both soils. The MDD of the red termite soil is consistently higher at all the RHA contents than that of gray termite soil type. These differences in MDD of both soils may be attributed to the types of surrounding soil used in building the termite hills.

The optimum moisture content (OMC) of the red termite is consistently lower than that of gray type. The unstabilized termite soil has the highest MDD of $1.67 \mathrm{~kg} / \mathrm{m}^{3}$ and OMC of $18 \%$ for red soil and the unstabilized gray type has $1.61 \mathrm{~kg} / \mathrm{m}^{3}$ MDD and OMC of $24.07 \%$.

Table 3: Compaction Test Results

\begin{tabular}{|l|l|l|}
\hline Percentage (\%) of RHA & $\begin{array}{l}\text { Maximum dry density (MDD) } \\
\mathrm{kg} / \mathrm{m}^{3}\end{array}$ & $\begin{array}{l}\text { Optimum moisture content } \\
(\mathrm{OMC}) \%\end{array}$ \\
\hline Red termite clay & \multicolumn{1}{|l|}{} \\
\hline 0 & 1.67 & 18.00 \\
\hline 2 & 1.61 & 18.00 \\
\hline 4 & 1.62 & 18.00 \\
\hline 6 & 1.64 & 18.00 \\
\hline 8 & 1.55 & 17.99 \\
\hline 10 & 1.58 & 18.00 \\
\hline Gray termite clay & \multicolumn{1}{|l|}{} \\
\hline 0 & 1.61 & 24.07 \\
\hline 2 & 1.59 & 23.99 \\
\hline 4 & 1.55 & 23.42 \\
\hline 6 & 1.50 & 24.00 \\
\hline 8 & 1.47 & 24.00 \\
\hline 10 & 1.48 & 24.00 \\
\hline
\end{tabular}

\subsection{Compressive Strength of Termite Clay Bricks}

The mean experimental results of compressive strength tests of termite clay bricks blended with different RHA contents burnt at two temperature levels of $800^{\circ} \mathrm{C}$ and $900^{\circ} \mathrm{C}$ are shown in Table 4. The compressive strength tests were in accordance with SON (1997) prescription. The results indicate higher values at firing temperature of $900^{\circ} \mathrm{C}$ than $800^{\circ} \mathrm{C}$ for both brick types.

The Gray termite clay bricks attained maximum compressive strength value of $11.75 \mathrm{~N} / \mathrm{mm}^{2}$ at $4 \% \mathrm{RHA}$ contents and at temperature of $900^{\circ} \mathrm{C}$. The compressive strength values of red termite bricks are lower than that of gray type for all the RHA contents and attained maximum values of $7.42 \mathrm{~N} / \mathrm{mm}^{2}$ at $6 \%$ RHA and at temperature of $900^{\circ} \mathrm{C}$. These strength values met the minimum specification, $5.2 \mathrm{~N} / \mathrm{mm}^{2}$ by BS3921: 1985 for common bricks. The results of the compressive strength of both gray and red termite clay bricks indicate low strength values but can be used for rural dwellings and partition walls where no serious load bearing is experienced. 
Table 4: Strength Properties of Burnt Termite Clay Bricks

\begin{tabular}{|c|c|c|c|c|}
\hline \multirow[t]{3}{*}{ RHA content, \% } & \multicolumn{4}{|c|}{ Compressive Strength, N/mm² } \\
\hline & \multicolumn{2}{|c|}{ Gray termite clay } & \multicolumn{2}{|c|}{ Red termite clay } \\
\hline & $800^{\circ} \mathrm{C}$ & $900^{\circ} \mathrm{C}$ & $800^{\circ} \mathrm{C}$ & $900^{\circ} \mathrm{C}$ \\
\hline 0 & 5.67 & 5.84 & 4.58 & 5.79 \\
\hline 2 & 6.17 & 6.96 & 4.67 & 5.08 \\
\hline 4 & 6.50 & 11.75 & 5.08 & 6.75 \\
\hline 6 & 4.83 & 5.83 & 5.25 & 7.42 \\
\hline 8 & 4.75 & 4.83 & 3.56 & 4.50 \\
\hline 10 & 5.42 & 5.33 & 4.42 & 4.42 \\
\hline
\end{tabular}

\subsection{Water Absorption Capacity of Bricks}

The water absorption test conducted in accordance with the procedure outlined in SON (1997) is cold water immersion of bricks for 24 hours. The results of water absorption (WA) of bricks fired at $800^{\circ} \mathrm{C}$ and $900^{\circ} \mathrm{C}$ for the gray and red termite clay bricks are presented in Table 5. The bricks fired at higher temperature of $900^{\circ} \mathrm{C}$ have lower WA than those fired at $800^{\circ} \mathrm{C}$ for both termite clay types. The bricks made of gray termite clay have low water absorption qualities than those made of red types at both fired temperature levels. The gray termite clay bricks have WA ranges between $13.4-22.9 \%$ and between $11.7-15.8 \%$ for $800^{\circ} \mathrm{C}$ and $900^{\circ} \mathrm{C}$, respectively. While the red termite clay bricks have WA ranges between $15.7-27.6 \%$ and $13.6-20.8 \%$ for $800^{\circ} \mathrm{C}$ and $900^{\circ} \mathrm{C}$, respectively. The results maintained increasing trend pattern with increase in RHA contents for both brick types.

The WA of gray termite bricks met the specification of not greater than $20 \%$ by BS5628 (1992). Apart from engineering bricks for class $A$ and $B$ for special types of construction which maintain minimum specification of $4-7.0 \%$ WA; all others have no limit specification according to BS3921: 1985.

Table 5: Water Absorption of Burnt Termite Clay Bricks

\begin{tabular}{|l|l|l|l|l|}
\hline \multirow{2}{*}{$\begin{array}{l}\text { RHA, content, } \\
\%\end{array}$} & \multicolumn{4}{|l|}{ Water Absorption, \% } \\
\cline { 2 - 5 } & Gray termite clay & Red termite clay & \\
\cline { 2 - 5 } & $800^{\circ} \mathrm{C}$ & $900^{\circ} \mathrm{C}$ & $800^{\circ} \mathrm{C}$ & $900^{\circ} \mathrm{C}$ \\
\hline 0 & 13.4 & 11.7 & 15.7 & 13.6 \\
\hline 2 & 15.0 & 12.6 & 17.5 & 14.5 \\
\hline 4 & 17.1 & 12.9 & 19.9 & 15.2 \\
\hline 6 & 19.3 & 12.8 & 21.4 & 16.4 \\
\hline 8 & 21.1 & 14.8 & 24.4 & 20.4 \\
\hline 10 & 22.9 & 15.8 & 27.6 & \multicolumn{2}{|l}{} \\
\hline
\end{tabular}

\subsection{Statistical Analysis}

The analysis of variance (ANOVA) was carried out to check if there is significant difference between the compressive strength obtained due to the types of the termite clay, RHA content and firing temperature of the burnt bricks. The compressive strength results data and the ANOVA results for gray termite clay blended with
RHA content are shown in Tables 6 and 7 while that of red termite clay type are presented in Tables 8 and 9 .

The results of the ANOVA indicate that there is no significant difference or effect due to RHA contents and firing temperatures for both clay types. Tables 10 14 results also indicate that termite clay type has no significant effect on the compressive strength property of the burnt bricks.

Table 6: Effect of RHA contents and firing temperature on compressive strength, $\mathrm{N} / \mathrm{mm}^{2}$ of Gray Termite Clay bricks

\begin{tabular}{|c|c|c|c|c|c|c|c|}
\hline \multirow[t]{2}{*}{ Temperature $\left({ }^{\circ} \mathrm{C}\right)$} & \multicolumn{7}{|c|}{ Rice Husk Content (RHA), \% } \\
\hline & 0 & 2 & 4 & 6 & 8 & 10 & Total \\
\hline \multirow[t]{4}{*}{800} & 5.50 & 5.50 & 5.75 & 5.00 & 4.75 & 5.75 & 32.25 \\
\hline & 6.00 & 7.50 & 8.00 & 4.50 & 4.75 & 5.75 & 36.50 \\
\hline & 5.50 & 5.50 & 5.75 & 5.00 & 4.75 & 4.75 & 31.25 \\
\hline & 17.0 & 18.5 & 19.5 & 14.5 & 14.25 & 16.25 & 100 \\
\hline \multirow[t]{4}{*}{900} & 6.25 & 6.13 & 12.50 & 5.00 & 5.00 & 5.75 & 40.63 \\
\hline & 5.63 & 8.50 & 12.75 & 6.25 & 4.50 & 5.25 & 42.88 \\
\hline & 5.63 & 6.25 & 10.00 & 6.25 & 5.00 & 5.00 & 38.13 \\
\hline & 17.51 & 20.88 & 35.25 & 17.5 & 14.5 & 16 & 121.64 \\
\hline Grand total & 34.51 & 39.38 & 54.75 & 32 & 28.75 & 32.25 & 221.64 \\
\hline
\end{tabular}


Table 7: ANOVA on the effects of RHA contents and firing temperature on the compressive strength for Gray Termite

\begin{tabular}{|l|l|l|l|l|l|}
\hline $\begin{array}{l}\text { Source } \\
\text { variation }\end{array}$ & D.F & S.S & M.S & $F_{\text {cal }}$ & $F_{\text {crit, }} \%$ \\
\hline C.F.M & 1 & 1364.564 & - & - & - \\
\hline RHA & 5 & 73.755 & 14.751 & $1.542^{\text {ns }}$ & 5.05 \\
\hline Temperature & 1 & 13.008 & 13.008 & $1.359^{\text {ns }}$ & 6.61 \\
\hline Error & 5 & 47.831 & 9.566 & 1 & - \\
\hline Total & 17 & 134.594 & - & - & - \\
\hline
\end{tabular}

D.F $=$ degree of freedom, $S S=$ sum of square, $M . S=$ mean square, $F_{\text {cal }}=F$ - calculated, $F_{\text {crit }}=F-$ critical, $n s=$ not significant, C.F.M. = correction factor for the mean.

Table 8: Effect of RHA contents and firing temperature on compressive strength results for red Termite bricks

\begin{tabular}{|c|c|c|c|c|c|c|c|}
\hline \multirow[t]{2}{*}{ Temperature $\left({ }^{0} \mathrm{C}\right)$} & \multicolumn{7}{|c|}{ RHA Content, \% } \\
\hline & 0 & 2 & 4 & 6 & 8 & 10 & total \\
\hline \multirow[t]{3}{*}{800} & 5.25 & 4.00 & 5.00 & 5.25 & 3.25 & 4.25 & 27.00 \\
\hline & 4.50 & 5.00 & 5.25 & 5.25 & 3.25 & 4.50 & 27.75 \\
\hline & 4.00 & 5.00 & 5.00 & 5.25 & 4.25 & 4.50 & 28.00 \\
\hline Total & 13.75 & 14.00 & 15.25 & 15.75 & 10.75 & 13.25 & 82.75 \\
\hline \multirow[t]{3}{*}{900} & 6.25 & 5.00 & 5.00 & 5.25 & 4.38 & 4.38 & 30.26 \\
\hline & 5.50 & 5.00 & 7.75 & 8.75 & 4.38 & 4.50 & 35.88 \\
\hline & 5.63 & 5.25 & 7.50 & 8.75 & 4.75 & 4.38 & 36.26 \\
\hline Total & 17.38 & 15.25 & 20.25 & 22.25 & 13.51 & 13.26 & 102.4 \\
\hline Grand total & 31.13 & 29.25 & 35.50 & 38.50 & 24.26 & 26.51 & 185.15 \\
\hline
\end{tabular}

Table 9: ANOVA on the effects of RHA contents and firing temperature on red termite clay bricks

\begin{tabular}{|l|l|l|l|l|l|}
\hline $\begin{array}{l}\text { Source } \\
\text { variation }\end{array}$ & D.F & S.S & M.S & $F_{\text {cal }}$ & $F_{\text {crit, } \%}$ \\
\hline C.F.M & 1 & 952.237 & - & - & - \\
\hline RHA & 5 & 24.174 & 4.835 & $1.163^{\text {ns }}$ & 5.05 \\
\hline Temperature & 1 & 10.725 & 10.725 & $2.579^{\text {ns }}$ & 6.61 \\
\hline Error & 5 & 20.799 & 4.159 & 1 & - \\
\hline Total & 17 & 55.698 & - & - & - \\
\hline
\end{tabular}

$D . F=$ degree of freedom, $S S=$ sum of square, $M . S=$ mean square, $F_{\text {cal }}=F$ - calculated, $F_{\text {crit }}=F-$ critical, $n s=$ not significant, C.F.M.= correction for the mean.

Table 10: Effect of Termite hill Types and RHA Contents at Temperature, $800^{\circ} \mathrm{C}$

\begin{tabular}{|l|l|l|l|l|l|l|l|}
\hline \multirow{2}{*}{$\begin{array}{l}\text { Termite } \\
\text { Type }\end{array}$} & hill & RHA content, \% & \multicolumn{7}{l|}{ Total } \\
\cline { 2 - 8 } Gray anthill & 0 & 2 & 4 & 6 & 8 & 10 & 3.75 \\
& 5.50 & 5.50 & 5.75 & 5.00 & 4.75 & 5.75 & 32.25 \\
\cline { 2 - 8 } & 6.00 & 7.50 & 8.00 & 4.50 & 4.75 & 5.75 & 36.5 \\
\cline { 2 - 8 } & 5.50 & 5.50 & 5.75 & 5.00 & 4.75 & 4.75 & 31.25 \\
\hline Total & 17 & 18.5 & 19.5 & 14.5 & 14.25 & 16.25 & 100 \\
\hline \multirow{3}{*}{ Red anthill } & 5.25 & 4.00 & 5.00 & 5.25 & 3.25 & 4.25 & 27 \\
\cline { 2 - 8 } & 4.50 & 5.00 & 5.25 & 5.25 & 3.25 & 4.50 & 27.75 \\
\cline { 2 - 8 } & 4.00 & 5.00 & 5.00 & 5.25 & 4.25 & 4.50 & 28 \\
\hline Total & 13.75 & 14.00 & 15.25 & 15.75 & 10.75 & 13.25 & 82.75 \\
\hline Grand total & 30.75 & 32.5 & 34.75 & 30.25 & 25 & 29.5 & 182.75 \\
\hline
\end{tabular}

Table 11: ANOVA on the effects of Termite clay type and RHA contents at $800^{\circ} \mathrm{C}$

\begin{tabular}{|l|l|l|l|l|l|}
\hline Source of variation & D.F & S.S & M.S & $F_{\text {cal }}$ & $F_{\text {crit, } 5 \%}$ \\
\hline C.F.M & 1 & 927.710 & - & - & - \\
\hline RHA & 5 & 8.905 & 1.781 & $0.689^{\text {ns }}$ & 5.05 \\
\hline Anthill type & 1 & 8.266 & 8.266 & $3.196^{\mathrm{ns}}$ & 6.06 \\
\hline Error & 5 & 12.932 & 2.586 & - & - \\
\hline Total & 11 & 30.102 & - & - & - \\
\hline
\end{tabular}

$D . F=$ degree of freedom, $S S=$ sum of square, $M . S=$ mean square, $F_{\text {cal }}=F-$ calculated, $F_{\text {crit }}=F-$ critical, $n s=$ not significant, C.F.M. $=$ correction factor for the mean. 
Table 12: Effect of Termite Clay Types and RHA Contents at Temperature, $900^{\circ} \mathrm{C}$

\begin{tabular}{|c|c|c|c|c|c|c|c|}
\hline \multirow{2}{*}{$\begin{array}{l}\text { Termite hill } \\
\text { type }\end{array}$} & \multicolumn{7}{|c|}{ RHA content, $\%$} \\
\hline & 0 & 2 & 4 & 6 & 8 & 10 & Total \\
\hline \multirow[t]{3}{*}{ Black anthill } & 6.25 & 6.13 & 12.50 & 5.00 & 5.00 & 5.75 & 40.63 \\
\hline & 5.63 & 8.50 & 7.75 & 6.25 & 4.75 & 5.25 & 38.13 \\
\hline & 5.63 & 6.25 & 10.0 & 6.25 & 5.00 & 5.00 & 38.13 \\
\hline Total & 17.51 & 20.88 & 30.25 & 17.5 & 14.75 & 16 & 116.89 \\
\hline \multirow{3}{*}{ Red anthill } & 6.25 & 5.00 & 5.00 & 5.25 & 4.38 & 4.38 & 30.26 \\
\hline & 5.50 & 5.00 & 7.75 & 8.75 & 4.38 & 4.50 & 35.88 \\
\hline & 5.63 & 5.25 & 7.50 & 8.75 & 4.75 & 4.38 & 36.26 \\
\hline Total & 17.38 & 15.25 & 20.25 & 22.75 & 13.51 & 13.26 & 102.40 \\
\hline Grand total & 34.89 & 36.13 & 50.50 & 40.25 & 28.26 & 29.26 & 219.29 \\
\hline
\end{tabular}

Table 13: ANOVA on the effects of Termite clay type and RHA contents at $900^{\circ} \mathrm{C}$

\begin{tabular}{|l|l|l|l|l|l|}
\hline Source of variation & D.F & S.S & M.S & $F_{\text {cal }}$ & $F_{\text {crit, }} \%$ \\
\hline C.F.M & 1 & 1335.781 & - & - & - \\
\hline RHA & 5 & 55.515 & 11.103 & $1.068^{\mathrm{ns}}$ & 5.05 \\
\hline Anthill & 1 & 5.832 & 5.832 & $0.5^{\mathrm{ns}}$ & 6.06 \\
\hline Error & 5 & 51.965 & 10.393 & - & - \\
\hline Total & 17 & 113.312 & - & - & - \\
\hline
\end{tabular}

D.F = degree of freedom, $S S=$ sum of square, $M . S=$ mean square, $F_{\text {cal }}=F-$ calculated, $F_{\text {crit }}=F-$ critical, $n s=$ not significant, C.F.M. = correction for the mean.

\section{CONCLUSION}

The physical and mechanical properties of gray and red termite clay soil were examined in this paper. The result of Table 1 shows that the two termite clay soils are within the low to medium plastic clay. They have low shrinkage and swelling potentials and are therefore good material for brick making. The compressive strength and water absorption capacity of bricks made of both red and gray termite clay soils were tested. The results values obtained for the compressive strength met the limit standard by BS3921: 1985 for common bricks.

The water absorption values also fall within the value stipulated by BS5628: 1992 for such structures as residential building structures. Both termite clay types can be stabilized with small quantity of RHA, about 4-6\% to improve its strength, to produce bricks that can be used for common structures like simple silo for food grain storages and human dwellings. Both termite clay bricks stabilized with RHA at $4-6 \%$ have compressive strengths greater than that specified in the British standard (BS5628 part1) of $2.80 \mathrm{~N} / \mathrm{mm}^{2}$ for residential buildings.

\section{REFERENCES}

Brady, N. C and Ray, R. W., 2006. Element of the nature and properties of soils. Prentice Hall, New Jessey, United States.

British Standards BS1377-2:., 1990. Methods of test for soil for civil engineering purposes, Part 2: classification tests, 1998.
British Standards BS3921:., 1985. Specifications for clay bricks, 1998.

British Standards BS5628:., 1992. Use of Masonry Part 1: Structural use of unreinforced masonry.

Chan, C., 2011. Effect of Natural Fibres Inclusion in Clay Bricks: Physico-Mechanical Properties, International Journal of Civil and Environmental Engineering 3, (1): $51-57$.

Demir, I., Baspinar, M. S and Orhan, M., 2005. Utilization of kraft pulp residues in clay brick production, Building and Environment, 40, (11): 1533-1537.

Demir, I., 2006. An investigation on the production of construction brick with processed waste tea", Building and Environment, 41, (9): 1274-1278.

Binici, H., Aksogan, O., Bakbak, D., Kaplan, H and Bilge, I., 2009. Sound insulation of fibre reinforced mud brick walls, Construction and Building Materials, 23, (2): 1035-1041.

Horng, Y. S., 2010. Compressive Strength study of brick masonry subjected to axial loading

Thesis submitted to the Faculty of Civil Engineering,Universiti Technologi, Malaysia.

Murray, M. J., Pepplinkhouse, H. J and Liversidge, R. M., 1981. Production of lightweight bricks and blocks utilising sawdust wastes, Division of Building Research Report, CSIRO, Australia. 
Makunza, J. K., 2006. Strengths of natural soil bricks, University of Dar Es Salaam, Department of Structural Engineering, "www.ks.trieste.it/media/137429/df4373.pdf.

Minjinyawa, Y, Lucas E. B and Adegunioye F. O., 2007. Termite mound clay as material for grain silo construction. Agricultural Engineering International: The CIGR E journal manuscript BC 07 002. Vol. IX.

Odumodu, R. C., 1999. Clay bricks industry in Nigeria, problem and prospects. Engineering focus 3, (6): 37-40.

Okeshola, I. K., 2012. Physico - Chemical and Engineering properties of termite hill as used in bricks construction", Thesis submitted to the University of Agriculture, Abeokuta online http: // www.unaab.edu.ng/journal/index.php/theses/the $\underline{\text { sis/1495 }}$

Oyetola, E. B., Abdullahi, M., 2006. The use of rice husk ash in low-cost sandcrete block production, Leonardo Electronic Journal of Practice and Technologies, 8: 58-70.

Rahman, M. A., 1987. Properties of clay-sand-rice husk ash mixed bricks", Cement Composites and Lightweight Concrete, 9, (2): 105-108.

Turgut, P. and Yesilata, B., 2008. Physico-mechanical and thermal performances of newly developed rubber-added bricks, Energy and Buildings, 40, (5): 679-688.

William, C. M., Hancode, R. G. V., Susan, A and Michael, A. V., 1995. Geochemistry and clay mineralogy of termite mound soil and the role of geography in chimlanzees of the Manhale mountains, Tanzania." Private Journal, 37, (2): 121 - 134.

Yetgin, Ş., Çavdar, O and Çavdar, A., 2008. The effects of the fibre contents on the mechanic properties of the adobes, Construction and Building Materials, 22, (3): 222-227. 